\title{
ANALISIS KELAYAKAN FINANSIAL PENINGKATAN KAPASITAS PRODUKSI SAPI POTONG
}

\section{FINANCIAL FEASIBILITY STUDY OF BEEF PRODUCTION CAPACITY EXPANSION}

\author{
MD Parlindungan1, A Yusdiarti1a, dan H Miftah'1 \\ 1 Program Studi Agribisnis, Fakultas Pertanian, Universitas Djuanda Bogor \\ Jl. Tol Ciawi No. 1, Kotak Pos 35 Ciawi, Bogor 16720. \\ a Korespondensi: Arti Yusdiarti, E-mail: arti.yoesdiarti@unida.ac.id \\ (Diterima: 12-09-2017; Ditelaah: 12-09-2017; Disetujui: 28-10-2017)
}

\begin{abstract}
This study was aimed to analyze the feasibility of production expansion of beef at CV Lembu Mas, Depok. CV Lembu Mas intended to expand their beef production, from 31 beef to 51 beef. The study was conducted at CV Lembu Mas from September to November 2016. Financial analysis was done to assess the benefit and the cost in this business and consisted of cost structure and cash flow analyzes using NPV and Payback Period parameters. Results showed that the NPV was NPV $>0=$ Rp 789.314.098. With profit-loss parameter, it was shown that the first year profit was Rp 128.440.450 and in year 2 to 5, the profit was Rp 209.408.450,-. The R/ C ratios were 1.1 in the first year and 1.2 in year 2 to 5 . Payback period was 1 year 11 months, shorter than the age of the business. Based on the results of financial and non financial analyzes, it was concluded that the expansion of production capacity was feasible.
\end{abstract}

Keywords: feasibility analysis, beef cattle, business development

\begin{abstract}
ABSTRAK
Analisis kelayakan peningkatan kapasitas produksi sapi potong ini bertujuan untuk menganalisis kelayakan finansial peningkatan usaha yang akan dilakukan oleh CV Lembu Mas. CV Lembu Mas bertujuan untuk meningkatkan usaha penggemukan sapinya dari 31 ekor per tahun menjadi 501 ekor per tahun. Penelitian dilaksanakan di CV Lembu Mas (Kelurahan Kedaung Kecamatan Sawangan Kota Depok Jawa Barat) mulai dari September sampai dengan November 2016. Analisis finansial dilakukan untuk mengetahui kelayakan usaha yaitu besar manfaat (benefit) dan besar biaya dalam usaha ini, yang dianalisis menggunakan analisis finansial, yang terdiri dari struktur biaya dan analisis cashflow dengan kriteria NPV, Payback period. Hasil NPV yang diperoleh NPV $>0=789.314 .098$. Kriteria Laba-Rugi peningkatan kapasitas produksi memperoleh keuntungan pada tahun pertama sebesar Rp 128.440.450, tahun kedua sampai tahun kelima memperoleh keuntungan sebesar : Rp 209.408.450. Kriteria $\mathrm{R} / \mathrm{C}$ Ratio diperoleh 1,1 pada tahun petama dan 1,2 pada tahun kedua sampai tahun kelima. Berdasarkan kriteria payback period yang diperoleh lebih cepat dari umur bisnis, yaitu 1 tahun 11 bulan. Berdasarkan aspek finansial, peningkatan kapasitas produksi dikatakan layak untuk dijalankan.
\end{abstract}

Kata kunci: analisis kelayakan, sapi potong, pengembangan usaha.

Parlindungan MD, A Yusdiarti, dan H Miftah. 2017. Analisis Kelayakan Finansial Peningkatan Kapasitas Produksi Sapi Potong. Jurnal Pertanian 8(2): 113-120. 


\section{PENDAHULUAN}

Indonesia merupakan negara yang berpotensi dalam pengembangan sektor agribisnis, salah satunya bidang peternakan. Pembangunan peternakan merupakan bagian yang erat dari pembangunan pertanian yang mendukung penyediaan pangan asal ternak yang bergizi. Pengembangan perternakan sangat dipengaruhi oleh pertambahan penduduk yang tiap tahunnya meningkat 1,49\% pertahun (BKKBN, 2015). Di masa mendatang, permintaan produksi ternak akan terus meningkat guna memenuhi kebutuhan protein hewani penduduk. Salah satu jenis ternak yang memberikan kontribusi besar terhadap pemenuhan kebutuhan sumber protein hewani masyarakat adalah sapi potong.

Jawa Barat, sebagai propinsi dengan populasi terpadat di Indonesia, mengalami kelangkaan produksi sapi. Perkembangan produksi, impor dan kebutuhan daging sapi di Jawa Barat tahun 2013 sampai dengan 2016 disajikan pada Gambar 1. Gambar 1 menunjukkan bahwa setiap tahunnya selalu ada selisih antara produksi dengan kebutuhan masyarakat. Jumlah permintaan daging sapi di Jawa Barat pada tahun 2014 mencapai 385.193 ton sedangkan jumlah produksi lokalnya 67.073 ton. Begitu juga tahun 2015 kebutuhan Jawa Barat mencapai 425.694 ton.

CV Lembu Mas adalah salah satu perusahaan yang bergerak dibidang peternakan sapi potong unit feedlot (penggemukan). CV Lembu Mas telah memiliki jaringan pasar yang luas baik untuk rumah potong hewan maupun konsumen akhir. Permintaan yang datang pada CV lembu Mas dari rumah potong hewan melebihi 60 ekor perbulan, sementara perusahaan hanya mampu memenuhi 5 ekor per bulan. Secara teknis, perusahaan menilai dirinya mampu untuk meningkatkan produksi dan dapat mengelola segala hal terkait budidaya sapi. CV Lembu Mas telah selangkah lebih maju dalam hal ransum pakan buatan sendiri dengan bahan-bahan yang relatif mudah untuk diperoleh. Oleh karena itu, maka penelitian ini bertujuan untuk melihat kelayakan finansial CV Lembu mas jika kapasitas produksi ditingkatkan dari sejumlah 31 ekor menjadi sejumlah 51 ekor (bertambah 20 ekor).

Namun, produksi lokal hanya mampu memenuhi 73.442 ton. Berdasarkan jumlah permintaan dan penawaran daging sapi di Jawa Barat, maka terdapat selisih sejumlah 318.120 ton pada tahun 2014 dan 350.216 pada tahun 2015 .

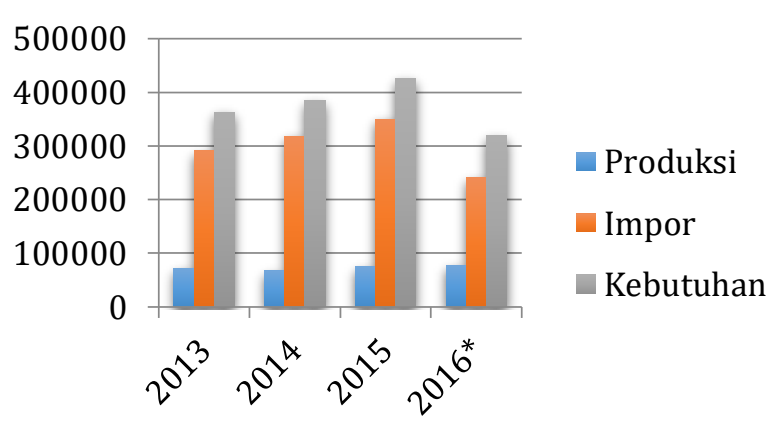

Sumber: Direktorat Jenderal Peternakan dan Kesehatan Hewan 2016

Gambar 1 Kebutuhan Daging Sapi di Jawa Barat Tahun 2013-2016 (ton)

\section{MATERI DAN METODE}

Penelitian ini dilaksanakan di CV Lembu Mas yang berlokasi di Jalan Cinangka Raya Gang Jambu RT 02 RW 04 Kedaung Sawangan, Kota Depok, Jawa Barat. Penelitian dilakukan selama 3 bulan terhitung mulai September sampai dengan November 2016. Data yang digunakan dalam penelitian ini diperoleh dari data primer dan sekunder. Data primer merupakan data yang dapat diperoleh langsung dari sumber asli melalui metode yang sesuai dengan masalah dan tujuan penelitian yaitu dengan cara wawancara ke pemilik (Bapak Thomas Budiarto), dan 3 orang karyawan yaitu : Maulana Malik Ibrahim pekerja lapang, Hendrik pekerja kandang, Takur sebagai kepala kandang.menggunakan kuesioner dan observasi di lapangan. Sedangkan data sekunder dari dokumen laporan data perusahaan, studi dari buku atau literatur skripsi dan laporan akhir, data dari Dinas Peternakan dan Badan Pusat Statistik (BPS).

Metode analisis yang digunakan dalam penelitian ini adalah metode analisis kuantitatif. Metode kuantitatif dilakukan untuk mengetahui kelayakan, peningkatan 
kapasitas produksi. Untuk mengetahuinya, maka dilakukan analisis terhadap berbagai aspek, mencakup aspek pasar, aspek teknis produksi, aspek lingkungan, aspek sosial ekonomi dan budaya. Setelah itu, maka akan dilakukan analisis terhadap aspek keuangan atau finansial, yaitu arus kas (Cash flow, NPV dan Payback Period, laporan Laba-Rugi, $R / C$ Ratio.

\section{HASIL DAN PEMBAHASAN}

Subsistem input ini membahas mengenai persiapan usaha, persiapan segala sesuatu yang diperlukan untuk kegiatan usaha berlangsung, ketersedian sumberdaya alam dan sarana prasarana produksi yang terdiri dari lahan, perkandangan, infastruktur, pengadaan sapi, dan tenaga kerja yang ada pada CV Lembu Mas.

Lahan yang digunakan oleh CV Lembu Mas ialah jenis lahan berkontur seluas $2.500 \mathrm{~m}^{2}$ dengan harga Rp 25.000 hingga Rp 500.000 per meter. Lahan yang digunakan untuk bangunan kandang seluas $1.500 \mathrm{~m}^{2}$ sedangkan sisa luas lahan yakni $1.000 \mathrm{~m}^{2}$ digunakan untuk fasilitas infrastruktur seperti jalan untuk alat transportasi, tempat parkir, tempat masak air minum, gudang pakan, rumah pemilik, kantor, dan lainnya digunakan sebagai lahan terbuka. Lahan yang akan dijadikan untuk peningkatan kapasitas produksi CV Lembu Mas adalah $100 \mathrm{~m}^{2}$ dengan asumsi membeli seharga Rp 500.000 per meter.

Tipe kandang menggunakan tipe kandang individu. Besarnya kandang individu yang dibangun sebesar $2 \mathrm{~m}$ x $1.2 \mathrm{~m}$. Infrastruktur yang berada di CV Lembu Mas antara lain : luas lahan, akses transfortasi, komunikasi, listrik untuk penerangan, ketersediaan air, dan sarana lain. Penerangan listrik perusahaan dengan kapasitas 6500 Watt yang digunakan sebagai penerangan kandang, rumah pemilik, dan sekitar perusahaan. Selain itu listrik digunakan untuk menyalakan pompa air. CV Lembu Mas memiliki ketersedian air sumur yang cukup dengan kedalaman 32 meter. Sarana dan prasarana lain yang dimiliki sebagai penunjang proses kegiatan usaha penggemukan antara lain, kandang, kantor dan rumah pemilik.

Pengadaan bahan baku untuk sapi bakalan yang ada di CV lembu Mas berasal dari para petani di Jawa Timur yaitu daerah Ponorogo dan Jawa Tengah yaitu daerah Jogja dan sekitarnya. Bakalan sapi di pilih berdasarkan kriteria yang telah ditetapkan seperti, bobot bakalan $300 \mathrm{~kg}$. Sementara untuk pengadaan bahan baku seperti hijauan diperoleh dari sekitar peternakan, kebutuhan hijauan untuk penambahan 20 ekor sapi adalah $600 \mathrm{~kg}$ perhari (30 kg/ekor) untuk bahan baku seperti ampas tahu dan sari kacang kedelai diperoleh dari perusahaaan pembuatan tahu. Kebutuhan ampas tahu untuk 20 ekor sapi adalah $100 \mathrm{~kg}$ perhari (4 karung dengan harga perkarungnya sebesar Rp 15.000), Kebutuhan hijauan perhari untuk 20 ekor sapi adalah $600 \mathrm{~kg}$, sedangkan untuk kebutuhan sari kedelai perhari untuk 20 ekor sapi adalah 120 liter atau 4 drigen 30 liter. Dengan harga per-derigennya $\mathrm{Rp}$ 5.000. kebutuhan ini masih dapat dipenuhi oleh perusahaan pembuatan tahu. Pengadaan peralatan untuk proses produksi CV Lembu Mas diperoleh dari berbagai tempat diantaranya seperti ember, sapu, pengki, parang dapat diperoleh di pasar tradisonal. Sementar untuk bahan baku seperti sekop, kayu, semen, pasir, dan lainnya diperoleh dari toko material di sekitar CV Lembu Mas.

Asumsi-asumsi dasar yang digunakan dalam perencanaan finansial adalah sebagai berikut.

1. Umur investasi bisnis adalah 5 tahun, hal ini ditentukan dari umur investasi yang paling lama dan berpengaruh dalam kegiatan bisnis yaitu investasi umur bangunan kandang dan mobil.

2. Biaya invetasi diasumsikan pada tahun pertama karena proses persiapan kandang dan sarana prasarana produksi lainnya membutuhkan waktu 3 bulan.

3. Modal yang digunakan untuk usaha ini yaitu modal sendiri.

4. Perhitungan biaya penyusutan atas investasi yang dilakukan berdasarkan metode garis lurus. Nilai sisa mobil adalah $50 \%$ dengan umur ekonomis 5 tahun. 
5. Setiap satu tahun dihitung 365 hari.

6. Usaha memiliki kewajiban membayar pajak penghasilan sesuai dengan peraturan perundang-undangan 46 tahun 2013 dimana penjualan di bawah 4.8M pertahun dikenakan pajak final sebesar 1 persen dari penjualan dan di atas 4.8 Milyar pertahun akan dikenakan final pajak sebesar 25 persen.

7. Tingkat mortalitas sebesar 0 persen

8. Diskon Rate yang digunakan adalah $7,1 \%$ berdasarkan suku bunga deposito bank BRI September 2016.

9. Jumlah produksi yang akan ditambah 20 ekor sapi, berdasarkan kapasitas lahan yang dimiliki dan modal yang dimliki.

10. Harga beli sapi bakalan konstan selama usaha berlangsung dengan dengan harga Rp15.000.000

11. Periode penggemukan sapi dari bakalan hingga panen membutuhkan waktu selama 3 bulan.
12. Harga jual sapi Rp 70.000 per kg dengan bobot hidup rata-rata $480 \mathrm{~kg}$ dan karkas $288 \mathrm{~kg}$.

\section{Analisis Finansial}

Biaya investasi biasanya dilakukan di tahun pertama usaha, dan ada beberapa barang investasi yang memerlukan reinvestasi jika umur ekonomisnya sudah habis. Berikut ini adalah investasi-investasi yang dilakukan CV. Lembu Mas untuk mengimplementasi pengembangan bisnis ini. Nilai sisa dalam peningkatan kapasitas produksi ini adalah $\mathrm{Rp}$ 52.807.700, terdiri dari nilai sisa kandang, kendaraan satu unit mobil, komputer, dan penyusutan peralatan yang masih memiliki nilai ekonomis setelah umur bisnisnya berakhir. Adapun biaya investasi yang dikeluarkan perusahaan dapat dilihat pada Tabel 1.

Tabel 1 Rencana investasi peningkatan kapasitas produksi CV Lembu Mas

\begin{tabular}{|c|c|c|c|c|c|c|}
\hline Keterangan & Jumlah & Satuan & Harga & Jumlah & $\begin{array}{c}\text { Umur } \\
\text { Ekonomis }\end{array}$ & Nilai \\
\hline Lahan & 100 & Meter & 500.000 & 50.000 .000 & & \\
\hline $\begin{array}{l}\text { Pembuatan } \\
\text { kandang }\end{array}$ & 2 & Blok & 10.000 .000 & 20.000 .000 & 5 Tahun & 500.000 \\
\hline Kendaraan & 1 & Unit & 100.000 .000 & & 5 Tahun & 50.000 .000 \\
\hline Komputer & 1 & Unit & 5.000 .000 & & 5 Tahun & 500.000 \\
\hline Jumlah & & & & & & 51.000 .000 \\
\hline $\begin{array}{l}\text { Penyusutan } \\
\text { peralatan }\end{array}$ & & & & & & 1.806 .200 \\
\hline Jumlah & & & & & & 52.807 .700 \\
\hline
\end{tabular}

\section{Pendapatan dan Biaya Operasional}

Pendapatan yang diterima oleh CV Lembu mas pada peningkatan kapasitas produksi ini adalah dari penjualan sapi. Pendapatan yang diterima pada tahun pertama dan tahun kedua berbeda karena pada tahun pertama CV Lembu mas hanya melakukan tiga siklus produksi. Sedangkan pada tahun kedua empat siklus produksi. Pendapatan yang diperoleh CV Lembu Mas pada tahun pertama adalah Rp 1.209.600.000. Dan pada tahun ke-dua sampai tahun ke-lima adalah Rp 1.612.800.000. Biaya variabel yang dikeluarkan oleh CV Lembu Mas untuk 20 ekor sapi per siklus produksi bisa dilihat pada Tabel 2.

Biaya variabel yang dikeluarkan dalam peningkatan kapasitas produksi dalam satu siklus produksi adalah untuk membeli bakalan sapi sebanyak 20 ekor dengan harga Rp 15.000.000, membeli ampas tahu sebanyak 4 karung perhari dengan harga $\mathrm{Rp}$ 15.000 perkarung atau 5.400 .000 per siklus produksi, membeli sari kedelai, bensin mesin babat, listrik Rp 100.000 perbulan atau Rp 300.000. Kebutuhan bensin mobil operasional 
Rp 900.000, biaya perawatan kendaraan Rp 450.000, membeli garam untuk campuran ampas tahu Rp 100.000, biaya obat-obatan sebanyak Rp 150.000 per ekor selama satu siklus produksi, dan upah tenaga kerja harian lepas pada saat panen dilakukan yaitu Rp 4.000.000 per siklus produksi atau $\mathrm{Rp}$
16.000.000 per-tahun. membeli pulsa sebanyak Rp 300.000 dan kebutuhan biaya lain-lain. Biaya variabel yang dikeluarkan dalam peningkatan kapasitas produksi ini dalam satu silus produksi adalah $\mathrm{Rp}$ 313.750 .000 atau $\mathrm{Rp}$ 1.271.000.000 per tahun.

Tabel 2 Biaya variabel peningkatan kapasitas produksi CV Lembu Mas

\begin{tabular}{lrr}
\hline Sapi (20 ekor) & Kebutuhan 1 Siklus Produksi & \multicolumn{1}{r}{ Per Tahun } \\
\hline Bakalan sapi & 300.000 .000 & 1.200 .000 .000 \\
Ampas tahu & 5.400 .000 & 21.600 .000 \\
Sari Kedelai & 1.800 .000 & 7.200 .000 \\
Bensin Mesin Babat & 1.350 .000 & 5.400 .000 \\
Listrik & 300.000 & 1.200 .000 \\
Transportasi & 900.000 & 3.600 .000 \\
Obat-obatan & 3.000 .000 & 12.000 .000 \\
Garam & 100.000 & 400.000 \\
Upah Tenaga Kerja Lepas & 4.000 .000 & 16.000 .00 \\
Pulsa & 300.000 & 1.200 .000 \\
Biaya lain-Lain & 600.000 & 2.400 .000 \\
Jumlah & 317.750 .000 & 1.271 .000 .000 \\
\hline
\end{tabular}

Rincian biaya tetap yang dikeluarkan oleh CV lembu Mas untuk 20 ekor sapi dapat dilihat pada Tabel 3.

Tabel 3 Biaya tetap peningkatan kapasitas produksi CV Lembu Mas

\begin{tabular}{lrr}
\hline \multicolumn{1}{c}{ Komponen } & Jumlah & \multicolumn{1}{c}{ Pertiga bulan } \\
\hline $\begin{array}{l}\text { Tambahan Gaji } \\
\text { Manager }\end{array}$ & 1 & 9.000 .000 \\
$\begin{array}{l}\text { Bonus Akhir } \\
\text { Tahun }\end{array}$ & 3 & 1.750 .000 \\
THR & 3 & 1.650 .000 \\
Gaji Karyawan & 2 & 12.000 .000 \\
Perawatan & 1 & 450.000 \\
Mesin & 2 & \\
Cangkul & 4 & 35.000 \\
Sekop Kotoran & 2 & 70.000 \\
Sekop makanan & 6 & 18.000 \\
Sapu Lidi & 12 & 30.000 \\
Gelas & 6 & 9.000 \\
Sikat & 2 & 18.000 \\
Parang & 1 & 25.000 \\
ATK & 2 & 10.000 \\
Pengki & & 10.000 \\
Biaya & & 3.990 .888 \\
Penyusutan & & \\
Jumlah & & Rp 29.065 .888 \\
\hline
\end{tabular}

Adapun biaya tetap yang dikeluarkan oleh peternakan CV Lembu Mas adalah gaji tambahan yang diinginkan oleh manager, gaji tambahan kayawan 2 orang, tunjangan hari raya, dan bonus akhir tahun. Biaya tetap yang dikeluarkan dalam peningkatan kapasitas produksi CV Lembu Mas adalah tambahan gaji manajer atau pemilik usaha Rp 9.000.000, bonus akhir tahun untuk dua orang karayawan Rp 4.000.000, bonus akhir tahun pemilik Rp 3.000.000 atau Rp.1.750.000. per tiga bulan, tunjangan hari raya dua orang karyawan $\mathrm{Rp} 3.600 .000$ dan tunjangan hari raya pemilik Rp 3.000.000 atau Rp1.650.000 per tiga bulan, gaji dua orang karyawan Rp 2.000.000 per bulan atau Rp 12 000.000. Biaya perawatan mesin Rp 450.000 pertiga bulan, dan ditambah dengan biaya peralatan yang habis dalam satu tahun. Kebutuhan biaya tetap dalam rencana peningkatan kapasitas produksi CV Lembu Mas adalah 29.065.888 pertiga bulan atau Rp 100.300.000 pertahun.

\section{Analisis Kelayakan Usaha Arus Kas (Cash flow)}

Total biaya investasi yang dikeluarkan pada tahun pertama adalah Rp 184.135.000 tahun kedua tidak ada, tahun ketiga $\mathrm{Rp}$ 1.775.000, 
tahun keempat tidak ada, tahun kelima $\mathrm{Rp}$ 1.775.000. berdasarkan pendapatan yang diterima CV Lembu Mas pada tahun pertama memperoleh pendapatan sebesar $\mathrm{Rp}$ 1.209.600.000 sedangkan tahun kedua sampai tahun kelima memperoleh pendapatan sebesar Rp 1.612.800.000. dan total biaya variabel $\mathrm{CV}$ Lembu Mas mengeluarkan biaya variabel sebesar $\mathrm{Rp}$ 953.250.000, kedua sampai tahun kelima sebesar Rp 1.271.000.000. Biaya tetap pada tahun pertama sebesar Rp 99.850.000 dan Rp 100.300 .000 pada tahun ke-dua sampai tahun ke-lima. Perbedaan biaya pada tahun pertama dan tahun kedua karena pada tahun pertama proses produksi dilakukan 3 siklus produksi, sedangkan pada tahun kedua sampai tahun kelima proses produksi dilakukan sebanyak 4 siklus. Hasil kelayakan usaha berdasarkan analisis cash flow dapat dilihat pada Tabel 4 .

Tabel 4 Kriteria kelayakan investasi peningkatan kapasitas produksi (000)

\begin{tabular}{lrrrrr}
\hline \multicolumn{1}{c}{$\begin{array}{c}\text { Kriteria } \\
\text { Investasi }\end{array}$} & Tahun 1 & Tahun 2 & Tahun 3 & Tahun 4 & \multicolumn{1}{c}{ Tahun 5 } \\
\hline Investasi & 184.135 & & 1.775 & & 1.775 \\
Pendapatan & 1.209 .600 & 1.612 .800 & 1.612 .800 & 1.612 .800 & 1.612 .800 \\
Biaya Variabel & 953.250 & 1.271 .000 & 1.271 .000 & 1.271 .000 & 1.271 .000 \\
Biaya Tetap & 99.850 & 100.300 & 100.300 & 100.300 & 100.300 \\
NPV & 789.314 & & & & \\
Payback Period & 1 tahun 11 bulan & & & & \\
\hline
\end{tabular}

\section{Laporan Laba/Rugi Persiklus Produksi}

Laporan laba rugi terdiri dari total penerimaan dan biaya-biaya yang dikeluarkan dalam menjalankan usaha. yaitu biaya tetap dan biaya variabel. Laporan laba rugi peningkatan kapasitas produksi CV Lembu Mas dapat dilihat pada tabel 5.

Menurut perhitungan Laba/Rugi peningkatan kapasitas ini memperoleh penerimaan Rp. 403.200.000, sedangkan biaya tetap yang dikeluarkan adalah sebesar Rp. 29.065.888, biaya variabel Rp. 317.750.000. Keuntungan yang diperoleh perusahaan dalam satu siklus produksi (3 bulan) adalah sebesar Rp. 42.786.817, berdasarkan kriteria $R / C$ ratio $>1$,yaitu 1,2 , artinya setiap biaya Rp. 1 menghasilkan penerimaan Rp.1,2. Degan demikian menurut perhitungan laporan laba rugi usaha peningkatan kapasitas produksi sapi potong ini dikatakan layak untuk dijalankan.

\section{Hasil Analisis Kelayakan Usaha (Cashflow)}

Berdasarkan hasil NPV yang diperoleh pada peningkatan kapasitas produksi ini dapat dikatakan layak karena $N P V>0=$ 789.314.098. Berdasarkan kriteria payback period (tingkat pengembalian investasi) juga dikatakan layak untuk dijalankan karena peningkatan kapasitas ini payback period yang diperoleh lebih cepat dari umur bisnis, yaitu 1 tahun 11 bulan. Dengan demikian dapat disimpulkan bahwa dari aspek finansial peningkatan kapasitas produksi ini layak.

Tabel 5 Laporan laba/rugi persiklus produksi (3 bulan)

\begin{tabular}{lcr}
\hline \multicolumn{1}{c}{ Penerimaan } & \multicolumn{2}{c}{ Rupiah } \\
\hline Pejualan Sapi & $\mathrm{Rp}$ & 403.200 .000 \\
1.Biaya Operasional & & \\
a. Biaya Tetap & & \\
Gaji Manager & $\mathrm{Rp}$ & 9.000 .000 \\
Bonus Akhir Tahun & $\mathrm{Rp}$ & 1.750 .000 \\
THR & $\mathrm{Rp}$ & 1.650 .000 \\
Gaji Karyawan & $\mathrm{Rp}$ & 12.000 .000 \\
Biaya perawatan & $\mathrm{Rp}$ & 450.000 \\
Mesin & & \\
Cangkul & $\mathrm{Rp}$ & 35.000 \\
Sekop Kotoran & $\mathrm{Rp}$ & 70.000 \\
Sekop makanan & $\mathrm{Rp}$ & 18.000 \\
Sapu Lidi & $\mathrm{Rp}$ & 30.000 \\
Gelas & $\mathrm{Rp}$ & 9.000 \\
Sikat & $\mathrm{Rp}$ & 18.000 \\
Parang & $\mathrm{Rp}$ & 25.000 \\
ATK & $\mathrm{Rp}$ & 10.000 \\
Pengki & $\mathrm{Rp}$ & 10.000 \\
Biaya Penyusutan & $\mathrm{Rp}$ & 3.990 .888 \\
Total Biaya Tetap & $\mathrm{Rp}$ & 29.065 .888 \\
b. Biaya Variabel & \multicolumn{2}{|}{} \\
\hline
\end{tabular}




\begin{tabular}{lcr}
\hline Bakalan sapi & $\mathrm{Rp}$ & 300.000 .000 \\
Ampas tahu & $\mathrm{Rp}$ & 5.400 .000 \\
Sari Kedelai & $\mathrm{Rp}$ & 1.800 .000 \\
Bensin Mesin Babat & $\mathrm{Rp}$ & 1.350 .000 \\
Listrik & $\mathrm{Rp}$ & 300.000 \\
Transportasi & $\mathrm{Rp}$ & 900.000 \\
Obat-obatan & $\mathrm{Rp}$ & 3.000 .000 \\
Garam & $\mathrm{Rp}$ & 100.000 \\
Upah Tenaga Kerja & $\mathrm{Rp}$ & 4.000 .000 \\
Lepas & & \\
Pulsa & $\mathrm{Rp}$ & 300.000 \\
Biaya lain-Lain & $\mathrm{Rp}$ & 600.000 \\
Jumlah & $\mathrm{Rp}$ & 317.750 .000 \\
Variabel & & \\
Total Biaya & $\mathrm{Rp}$ & 346.815 .888 \\
Operasional & & \\
Laba Kotor & $\mathrm{Rp}$ & 56.384 .112 \\
Pajak 1\% & $\mathrm{Rp}$ & 4.032 .000 \\
R/C Ratio & & 1,2 \\
Laba Setelah Pajak & $\mathrm{Rp}$ & 52.352 .112 \\
\hline
\end{tabular}

\section{KESIMPULAN DAN IMPLIKASI}

Berdasarkan hasil penelitian analisis peningkatan kapasitas produksi dan strategi pencapaiannya di CV Lembu Mas, dari hasil NPV yang diperoleh pada peningkatan kapasitas produksi ini adalah sangat layak, karena NPV > $0=\operatorname{Rp~789.314.098.~}$ Perhitungan Laba Rugi peningkatan kapasitas ini memperoleh keuntungan pada tahun pertama sebesar Rp 128.440.450, dan pada tahun kedua sampai tahun kelima memperoleh keuntungan sebesar: Rp. 209.208.450. Berdasarkan Kriteria R/C Ratio diperoleh 1,1 pada tahun petama dan 1,2 pada tahun kedua sampai tahun kelima,berdasarkan kriteria $R / C$ Ratio Masih dikatakan layak karena $>1$. Sedangkan berdasarkan kriteria payback period (tingkat pengembalian investasi) juga dikatakan layak untuk dijalankan karena peningkatan kapasitas ini payback period yang diperoleh lebih cepat dari umur bisnis, yaitu 1 tahun 11 bulan.

Berdasarkan hasil penelitian analisis peningkatan kapasitas produksi, Perusahaan disarankan melakukan peningkatan kapasitas produksi karena berdasarkan hasil penelitian yang dilakukan peningktan kapasitas produksi layak di jalankan baik dari aspek non finansial maupun finansial. Meskipun pasokan sapi potong dan bahan baku untuk operasional usaha seperti hijauan, ampas tahu, sari kedelai telah tersedia, namun hendakya CV Lembu Mas menjalin kerjasama pemasok untuk menjamin kontinuitas produk dan kepastian spesifikasi bahan baku yang dapat menunjang kontinuitas produksi dan menghemat biaya pencarían bahan baku.

\section{DAFTAR PUSTAKA}

Abidin Z.2005. Meningkatkan Produktivitas Puyuh. Jakarta: Agromedia Pustaka.

Bagus Y. 2012.Analisis Kelayakan Finansial Peternakan Burung Puyuh Dan Prospek Pengembangan Peternakan Puyuh Surya Unggas Jaya.[skripsi]. Fakultas Pertanian, Institut Pertanian Bogor.

David FR. 2006. Strategic Management. Edisi 10. Jakarta: Salemba Empat.

David Hunger J, Thomas L.Wheelen. 2003. Manajemen Sreategis. Yogyakarta: Penerbit Andi.

Direktorat Jenderal Peternakan dan Kesehatan Hewan Kementerian Pertanian. Peternakan dan Kesehatan Hewan, 20092013.Http: //ditjennak.deptan.go.id [6 Juni 2014]

Direktorat Jenderal Peternakan dan Kesehatan Hewan Kementerian Pertanian. Statistik Peternakan dan Kesehatan Hewan, $2016 . \quad$ http: //ditjennak.pertanian.go.id [ Juli 2016]

Gaspersz V. 2003. Ekonomi Manajerial Pembuatan Keputusan Bisnis. Edisi Revisi dan Perluasan. Jakarta: Gramedia Pustaka Utama.

Haris B. 2012. Analisis Neraca Perdagangan Peternakan Danswasembada Daging Sapi 2014. Jurnal Agribisnis dan Pengembangan Wilayah Vol. 1 No. 2, Juli 2010.75 : 218-235 Hernanto F. 1989. Ilmu Usahatani. Jakarta: Penebar Swadaya.

Ibrahim Y. 2009. Studi Kelayakan Bisnis. Jakarta: Rineka Cipta

Iwan SA.2007. Memanfaatkan Kotoran Ternak : edisi revisi. Jakarta Penebar Swadaya.

Karyadi D. 2008. Strategi Pengembangan Usaha Peternakan Rakyat (studi kasus Desa Cigudeg, Kecamatan Cigudeg, 
Kabupaten Bogor) [skripsi]. Bogor: Fakultas Peternakan, Institut Pertanian Bogor.

Kotler P, Keller KL. 2009. Manajemen Pemasaran: Analisis,edisi13. Jakarta : Gramedia Pustaka Utama

Muttaqien I. 2007. Strategi Pemasaran Kampoeng Ternak Baznas Dompet Dhuafa Republika [skripsi]. Bogor: Fakultas Pertanian, Institut Pertanian Bogor.

Nangoi R. 1998. Pengembangan Produksi dan Sumberdaya Manusia. Jakarta: PT. Raja Grafindo Persada.

Nurmalina R, Sarianti T, Karyanti A. 2014. Studi Kelayakan Bisnis. Bogor: Departemen Agribisnis FEM-IPB

Nuryati L, Yasin A, Indarti D, Kencana R, Suandi. Pusat Data dan sistem Informasi Pertanian Sekretariat Jenderal Kementrian pertanian.

WWW. epublikasi.setjen.pertanian.go.id [20 Mei 2015]

Pearce JA. Robinson B. 1997. Manajemen Strategi, Formulasi, Implementasi, dan Pengendalian. Jakarta: Binarupa Aksara.

Pertumbuhan Penduduk 2015. Pikiran Rakyat.www. pikiran rakyat.com [29 Mei 2015]

Rahardja P, Manurung M. 2004. Pengantar ilmu Ekonomi (Mikroekonomi \& Makroekonomi). Edisi Revisi. Jakarta: Penerbit Fakulatas Ekonomi Universitas Indonesia.
Riani TU.2015. Analisis Kelayakan Usaha Ternak Sapi Potong Pada Berbagai Skala Kepemilikan. [skripsi]. Makassar: Fakultas Pertanian, Universitas Hasanudin.

Ridha RN.2015. Analisis Kelayakan Usaha Pembibitan Sapi Peterrnakan Ongole Pola Gaduhan Dengan Bantuan PSBP dan PPBB dikelompok Andini Mulyo Sawahan.[skripsi]. Bogor: Fakultas Pertanian, Institut Pertanian Bogor.

Rina O Br Barus. 2014. Kajian Pengembangan Bisnis Peningkatan Produksi Telur Puyuh Melalui Penambahan Populasi Burung Puyuh di CV Slamet Quail Farm.[skripsi]. Bogor: Fakultas Pertanian, Institut Pertanian Bogor.

Santoso. 2012. Analisis Kemitraan Dan Strategi Pemasaran Sayuran Komersial [skripsi]. Bogor: Fakultas Pertanian, Institut Pertanian Bogor.

Sapibagus. Peluang dan Tantagan Bisnis Sapi Potong 2016. www. Sapibagus.com. [01 Januari 2016]

Soekartawi. 2002. Analisis Usahatani. Jakarta: Universitas Indonesia.

Soekartawi, Soeharjo A, Dillon JL, Handaker. 1986. Ilmu Usahatani dan Penelitian untuk Pengembangan Petani Kecil. Jakarta: Universitas Indonesia.

Suratiyah K. 2008. Ilmu Usahatani. Jakarta: Penebar Swadaya.

Umar H. 2008. Strategic Management in Action. Jakarta: Gramedia Pustaka Utama. 